\title{
ESTIMATION OF HYDRO-METEOROLOGICAL EXTREMES IN BEAS BASIN OVER HISTORIC, PRESENT AND FUTURE SCENARIO
}

\author{
Vishal Sharma ${ }^{1}$, Bhaskar R. Nikam ${ }^{1}$, Praveen K. Thakur ${ }^{1}$, Vaibhav Garg ${ }^{1}$, S. P. Aggarwal ${ }^{1}$, S. K. Srivastav ${ }^{1}$, Prakash Chauhan ${ }^{1}$ \\ ${ }^{1}$ Indian Institute of Remote Sensing, 4, Kalidas Road, Dehradun 248001, India, (vishalsharma, bhaskarnikam, Praveen, vaibhav, spa, \\ sksrivastav, prakash)@iirs.gov.in \\ *Corresponding author: vishalsharma@iirs.gov.in, vishal.iirs@gmail.com
}

KEY WORDS: Cloudburst, ERA-Interim, CORDEX, Variable Infiltration Capacity, hydro-meteorological, sustainable development.

\begin{abstract}
:
The North West Himalayan basins have always been prone to hydro-meteorological disasters. Among them Beas Basin is one of the highly affected basins. Beas basin is prone to cloudburst which causes huge loss to life and property every year. Increase in these devastating events have been noticed in the recent years. Climatic change is considered as the major driver for this increased occurrence of these events in the recent past. The analysis of long-term hydrological extremes over the basin will help in understanding the pattern of the hydro-meteorological extremes and also predicting its nature in near and far future. The Variable Infiltration Capacity (VIC) model at the grid size of $0.025^{\circ} \times 0.025^{\circ}$ has been used in the present study, for simulating the hydrological behaviour of the Beas Basin. The parameterization of the model inputs is derived from Remote Sensing based and field observed datasets. The model was forced with meteorological dataset of ERA-Interim for the past and present time period and CORDEX dataset for the future time period. The model was calibrated using observed discharge data of Nadaun and Sujanpur stations. The Nash-Sutcliffe model efficiency of calibrated model was achieved to be 0.77 and 0.72 and coefficient of determination $\left(\mathrm{R}^{2}\right)$ was 0.80 and 0.72 , respectively. The validation results of the model for the same stations shows the model efficiency to be 0.73 and 0.74 with coefficient of determination $\left(\mathrm{R}^{2}\right)$ as 0.67 and 0.82 , respectively. The well calibrated model was used to simulate the hydrological behaviour of historic period (1979 -2000), present period (2001 - 2017), near future period (2018 - 2050) and far future period (2051 - 2099). The exceedance probability curve method has been utilized in estimating the flood peak value for the future time period. The flood peak discharge value for the future time period comes out to be $1050 \mathrm{~m}^{3} / \mathrm{s}$. The hydro- meteorological extremes rate per year in each period was found to be 9,9 , 12 and 14, respectively. The hydro-meteorological extremes rate is showing increasing trend in near future and very high increase in far future. The study highlights the probability of occurrence of catastrophic events in coming future. The methodology and results of the present study can be beneficial for sustainable development of the basin to counter the effect of probable hydro-meteorological extremes in coming future.
\end{abstract}

\section{INTRODUCTION}

\subsection{Introduction}

Hydro-meteorological disasters are accumulating worldwide in the last decades and are giving clear indications of the climate related risks that are becoming even more damaging (Hattermann 2019). The assessment of hydro-meteorological events over the past, present and future helps us in assessing the climate change over the region and also makes us more aware and informative to plan about the coming dangerous events. However, information about future events are not available and hence the Variable Infiltration Capacity (VIC) (Liang et al. 1994; Liang, Wood, and Lettenmaier 1996) model is utilised for predicting the future events. It simulates snow accumulation and snowmelt, evapotranspiration, surface runoff, macro pore flow, tile drainage, groundwater outflow from soil layers, routing through rivers and retention and outflow from lakes and reservoirs, both natural and regulated (Donnelly, Yang, and Dahné 2014; Pechlivanidis et al. 2017; Towler et al. 2010). North Western Himalaya has always been prone to hydro-meteorological extremes and among in it, the Beas Basin is more prone to such flood events. (Aggarwal et al., 2016; Gupta et al., 1982; Naha et al., 2016; Prasad \& Roy, 2005) It also receives the highest annual rainfall with most number of rainfall extreme events. The high hilly terrain does not allow flood water to retain, instead the heavy rainfall triggers the occurrence of flash flood which causes huge damage to the basin. The Kullu and Manali stretch in the Beas Basin are most frequent for flash flood events. Number of cloudburst events happens in this area every year, causing huge damage to the life and property. The few flash flood event that occurred and are recorded in literature are 1990, 1991, 1992, 1993 and 1995 (Dhote et al. 2018; Dimri et al. 2017; Sati and Gahalaut 2013; Thakur et al. 2019; Thayyen et al. 2013) and Manali cloud burst induced flash flood-1995 and 2012 (State Disaster Cell, H.P. 2012; Thakur et al. 2019) are some most severe events. The flash flood occurs in almost every year in the basin. From 1990 onwards more than 30 flash flood events have occurred in the basin. It is very much prone to cloudburst and flash flood event that are reflected in the discharge at downstream stations. The frequency of extreme discharge events will help us in understanding the frequency of rainfall induced extreme events in the future simulations.

\section{STUDY AREA AND DATASETS USED}

\subsection{Study Area}

The Beas Basin (Figure 1) lies in the extent between at $31^{\circ} 30^{\prime} \mathrm{N}$ to $32^{\circ} 30^{\prime} \mathrm{N}$ latitude and $76^{\circ} 00^{\prime} \mathrm{E}$ to $78^{\circ} 00^{\prime} \mathrm{E}$ longitude. The river Beas originates from the Pir Panjal Range close to the Rohtang Pass, after this it flows through Kullu and Manali. It flows through Mandi and joins Satluj River near Harika. The river is very much prone to the flash floods events. The total area of the Beas Basin is approx. $12612 \mathrm{~km}^{2}$. The long term annual average precipitation observed is around $1301 \mathrm{~mm}$ with minimum annual precipitation of $808.03 \mathrm{~mm}$ and maximum annual precipitation of $2789.72 \mathrm{~mm}$. 


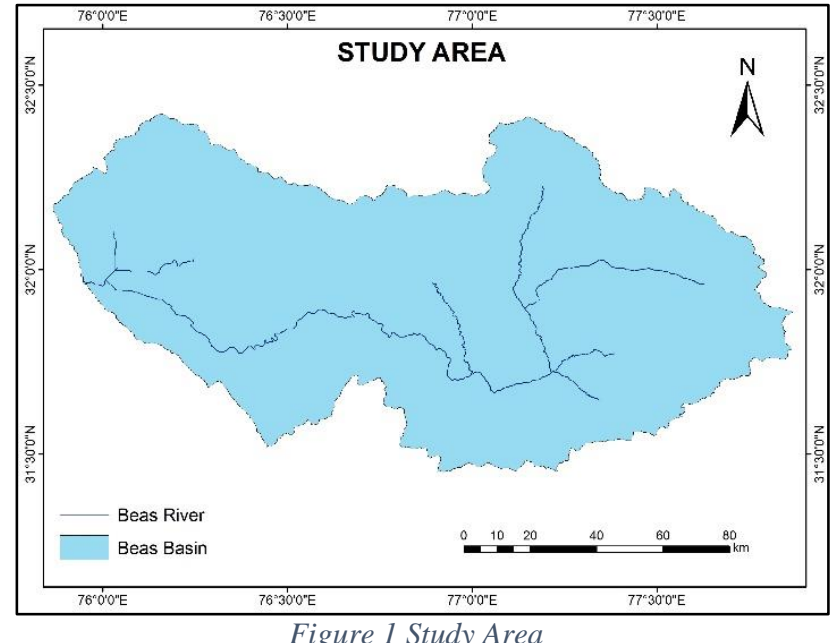

\subsection{Datasets Used}

The input parameters of VIC model, requires various types of data that involves remote sensing as well as various other datasets i.e. long-term hydro-meteorological datasets for the simulation period, observed discharge data for the calibration and validation of the model simulations, etc. The various remote sensing dataset helps us in estimating the near real time parameters that involves Land use type, Leaf area index (LAI), Snow Cover, etc. for each grid and is stored in the input parameter files.

The details of datasets used in the present study are provided in Table 1.

Table 1 Datasets Used

\begin{tabular}{|c|c|c|c|}
\hline A. & Remote Sensing & Resolution & Source / Datatype \\
\hline & $\begin{array}{l}\text { Digital Elevation } \\
\text { Model; Figure } 2\end{array}$ & $30 \mathrm{~m} \times 30 \mathrm{~m}$ & ASTER \\
\hline & $\begin{array}{c}\text { Land Use Land Cover } \\
\text { Figure } 3\end{array}$ & $100 \mathrm{~m} \mathrm{X} \mathrm{100m}$ & ISRO-GBP \\
\hline & LAI & $500 \mathrm{~m} X 500 \mathrm{~m}$ & MODIS \\
\hline & Snow Cover & $500 \mathrm{~m} \times 500 \mathrm{~m}$ & MODIS \\
\hline \multirow[t]{4}{*}{ B. } & $\begin{array}{c}\text { Hydro- } \\
\text { meteorological data }\end{array}$ & Resolution & \\
\hline & Era-Interim & $0.5^{\circ} \times 0.5^{\circ}$ & ECMWF \\
\hline & APHRODITE & $0.5^{\circ} \times 0.5^{\circ}$ & www.chikyu.ac.jp \\
\hline & CORDEX & $0.5^{\circ} \times 0.5^{\circ}$ & www.cordex.org \\
\hline \multirow[t]{3}{*}{ C. } & Secondary datasets & & \\
\hline & $\begin{array}{l}\text { Soil Data (FAO- } \\
\text { HWSD); Figure } 4\end{array}$ & $100 \mathrm{~m} \times 100 \mathrm{~m}$ & FAO \\
\hline & $\begin{array}{c}\text { Observed Discharge } \\
\text { Data }\end{array}$ & Monthly & $\begin{array}{c}\text { Bhakra Beas Management } \\
\text { Board (BBMB) }\end{array}$ \\
\hline \multirow[t]{4}{*}{ D. } & $\begin{array}{c}\text { Software's and } \\
\text { Tools Used }\end{array}$ & & \\
\hline & ArcGIS, QGIS & & \\
\hline & VIC Tool, Python & & \\
\hline & $\begin{array}{l}\text { VIC Model (VIC } 4.2 \\
\text { Glacier Model) }\end{array}$ & & https://vic.readthedocs.io \\
\hline
\end{tabular}

The various products utilised in the study are shown below as images.
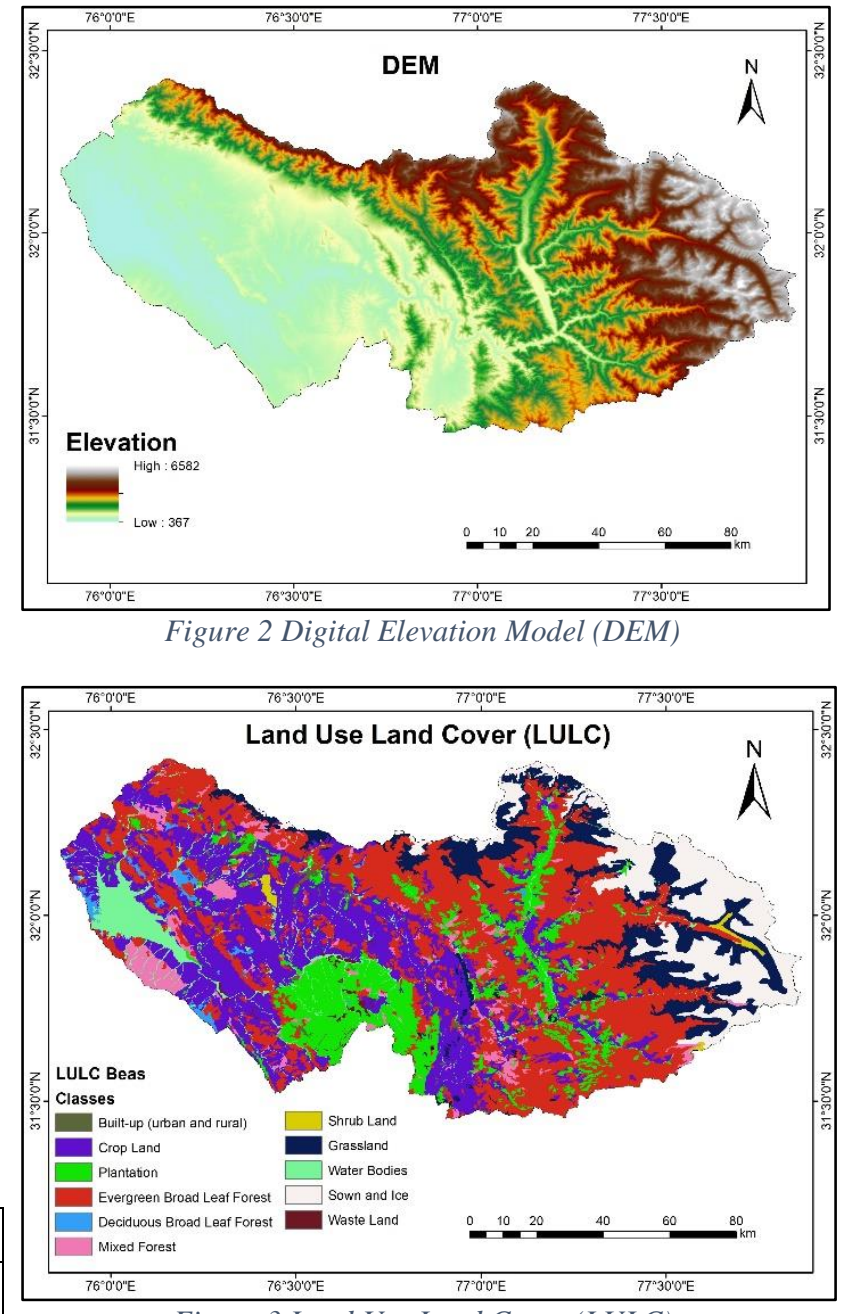

Figure 3 Land Use Land Cover (LULC)

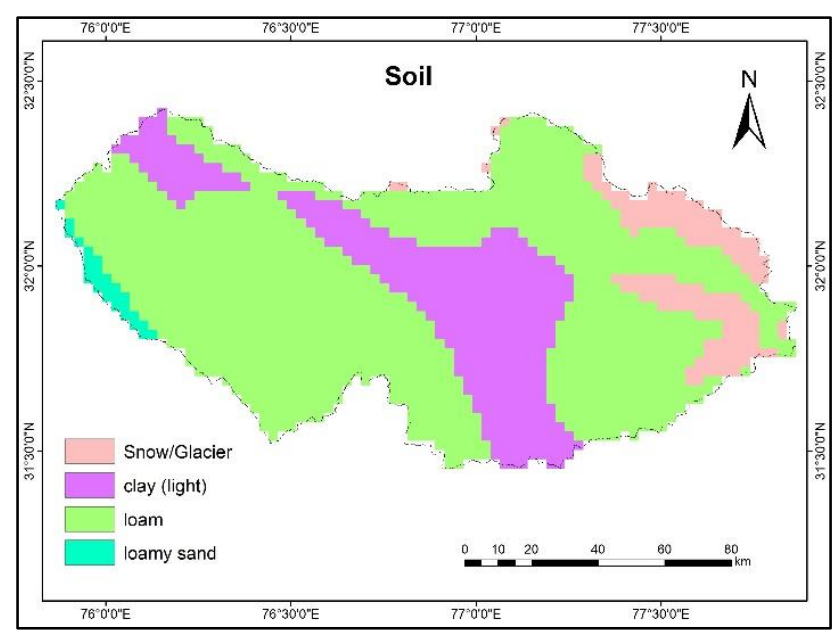

Figure 4 Soil Map

\section{METHODOLOGY}

As the current study is focused on the estimation of the hydrological extremes over the historic, present and future time periods, it requires the simulations for all the three time periods. The Variable Infiltration Capacity (VIC) (Lohmann and Raschke 2003; Gunderson et al. 1996; Terradas and Peñuelas 2008; X. Liang et al. 1994; Liang, Lettenmaier, and Wood 1996; Liang, Wood, and Lettenmaier 1996; Lohmann et al. 1998; Nijssen et al. 
1997) model is utilized for the generation of the simulations for the three time periods i.e. past (1979 - 2000), present (2001 2018) and future (2019 - 2099). The study is also performed in three phases-

1. Setting up of Hydrological model

2. Calibration and Validation of model Setup

3. Estimation of hydrologic extremes in historic, present and future.

The broad methodology adopted in the present study is shown in the Figure 5 below.

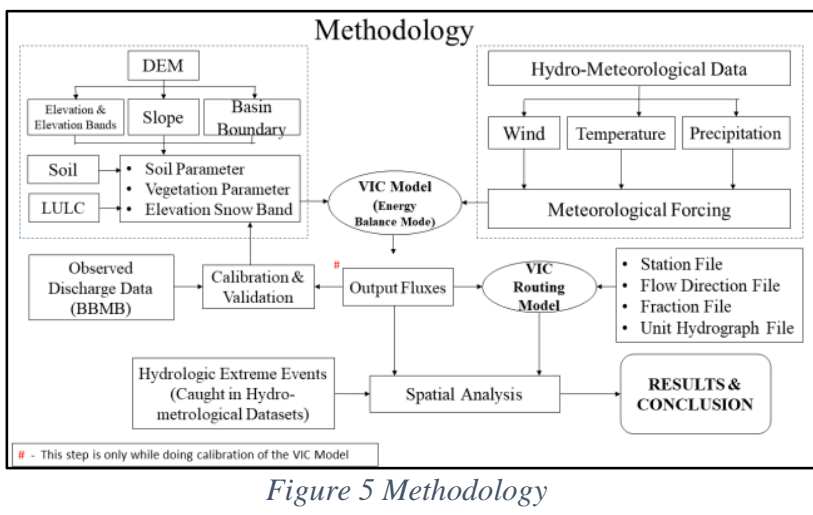

\subsection{Setting up of VIC Hydrological Model}

The setting up of hydrological model requires the creation of input parameters from various datasets. The Digital Elevation Model (DEM) is utilized for extracting the slope, elevation and elevation band file for each grid. The DEM is also utilized in extracting the basin boundary. The soil and LULC, Snow Cover datasets along with the above parameters are utilized in the creation of the Soil Parameter, Vegetation Parameter and Snow Band Files. The Hydro-meteorological datasets which contains daily information of wind speed, temperature and precipitation for all the three time-period are utilized in the creation of the meteorological forcing file. The input parameters along with the meteorological forcing are fed to the VIC hydrological model for the generation of the simulations for the specified time period. The study area is discretised into square grids of $0.25^{\circ} \times 0.25^{\circ}$ and the grids falling under study basin are assigned active/run status for setting up/running the VIC model. The active grid of Beas Basin are shown in Figure 6. The model is run in energy balance model at daily time step. VIC writes the daily surface energy balance and water balance outputs of each active grid in respective flux file of each grid. These fluxes are further used for generation of routed surface runoff and snow melt runoff component at various gauging stations in the basin. The simulated and observed discharge are compared to guide us in calibrating the complex VIC model.

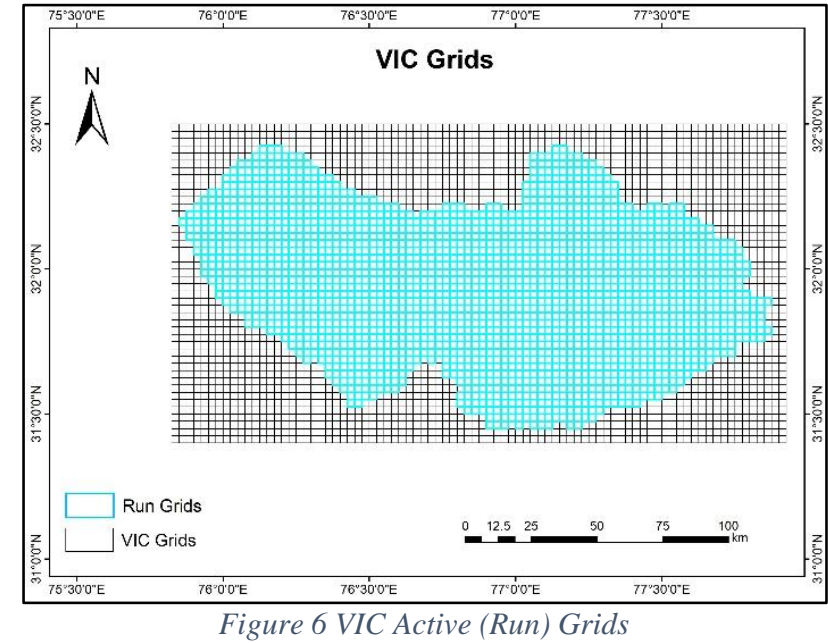

\subsection{Calibration and Validation}

The calibration and the validation are the further step following the simulation run. The fluxes are then routed at the outlets using the VIC Routing Model (Lohmann, D., Nolte-Holube, R. and Raschke 1996; Lohmann et al. 1998; LOHMANN et al. 1998)at specific station, where the observed discharge data is available for comparison, to get discharge as output. The simulated discharge is then compared with the observed discharge. The calibration parameters as suggested by Behera et al. (2019), Garg et al. $(2017 ; 2019)$ and Nikam et al. (2018) are changed and the model is simulated again. It is done till the simulated and observed discharge came in acceptable range. The simulated discharge is compared with the observed discharge of the validation period. The model is termed as well calibrated model and is then used for the further study. If the modelled discharge agrees well with the observed values for the validation period.

\subsection{Estimation of hydrologic extremes in historic, present and future}

The hydrologic extremes for the Beas basin are first identified from the historic reports. On the basis of the reports the flash flood peaks were identified and are marked as thresholds. The daily simulations are then utilized to identify the occurrence of the hydrologic extremes in the historic and present time period using the aforementioned flash flood discharge threshold. The exceedance curve (McMahan, Grover, and Vignola 2013) method is used in identifying the threshold for the future flash flood events. The total events during each time periods are noted and conclusions are drawn after normalizing all the events on the per year basis.

\section{RESULTS AND DISCUSSIONS}

\subsection{Calibration and Validation}

The observed discharge data of two outlets Nadaun and Sujanpur was obtained from Bhakara Beas Management Board (BBMB) for the period 2007 to 2015 . The model calibration and validation is done at these outlets for Beas Basin.

\subsubsection{Calibration}

The calibration periods chosen for Nadaun and Sujanpur outlet are from 2007 to 2010 and from 2008 to 2010, respectively. The simulated discharge data is plotted against the observed discharge data in order to compare the trend followed by the simulated discharge. The Nash- Sutcliffe efficiency and coefficient of determination $\left(\mathrm{R}^{2}\right)$ are considered as model performance 
evaluation parameters. Figure 7 and Figure 8 shows the close match of observed discharge data with model simulated discharge at both the stations.

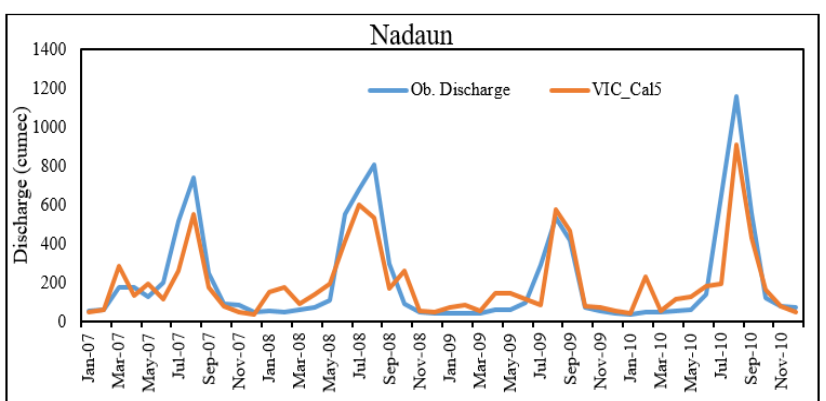

Figure 7 Plot of simulated and observed discharge at Nadaun during calibration period.

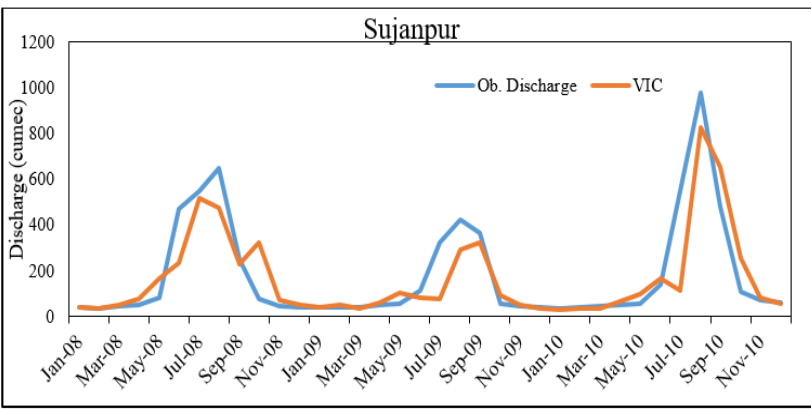

Figure 8 Plot of simulated and observed discharge at Sujanpur during calibration period.

The plots show the matching pattern in the simulated and the observed discharge. The Nash- Sutcliffe efficiency is also calculated at both the outlets and it is found to be 0.77 and 0.72 at Nadaun and Sujanpur, respectively. The Nash- Sutcliffe efficiency shows that the model parameter used in the model are well acceptable to simulate hydrological behaviour of the Beas Basin. The scatter plots generated for the observed and simulated discharge at the two outlets are shown in Figure 9 and Figure 10.

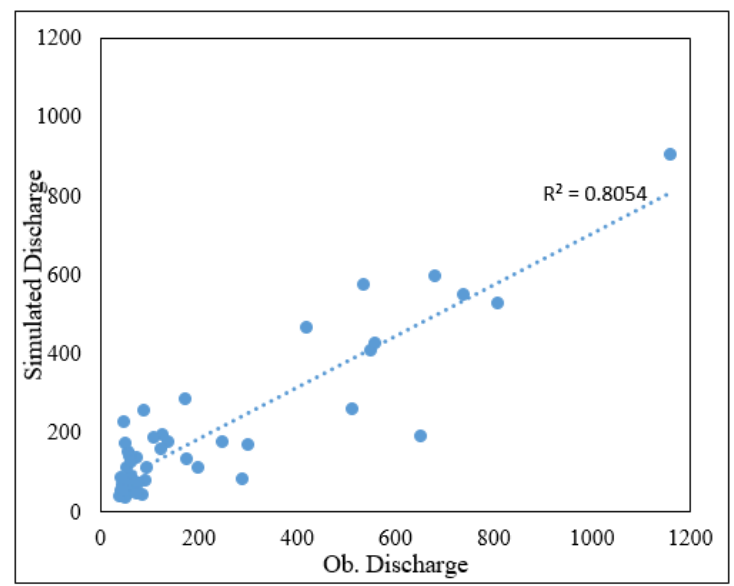

Figure 9 Scatter Plot at Naduan outlet

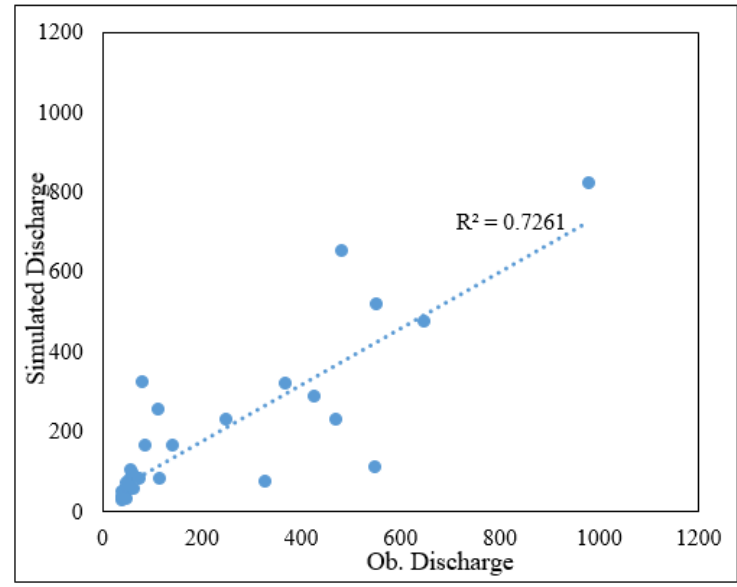

Figure 10 Scatter plot at Sujanpur outlet

The Scatter plots shows the high degree of correlation between the observed and simulated discharge. The values of coefficient of determination $\left(\mathrm{R}^{2}\right)$ for Nadaun and Sujanpur outlet are 0.81 and 0.73 , respectively. All the model performance parameter values obtained are under acceptable limits and supports the model calibration at Beas basin.

\subsubsection{Validation}

The period for which the validation of the calibrated VIC is from year 2012 to year 2015 for Nadaun outlet and from year 2013 to year 2015 for Sujanpur outlet as per the availability of observed data. The plot between the simulated and observed discharge are also generated in order to observe the behaviour of simulated discharge with the observed discharge pattern. The Figure 11 Figure 12 shows the behaviour of simulated discharge with the observed discharge.

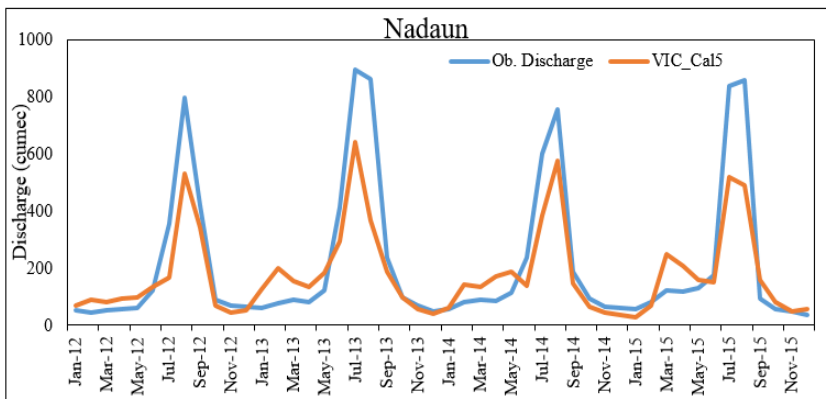

Figure 11 Validation plot of Simulated and observed Discharge at Nadaun

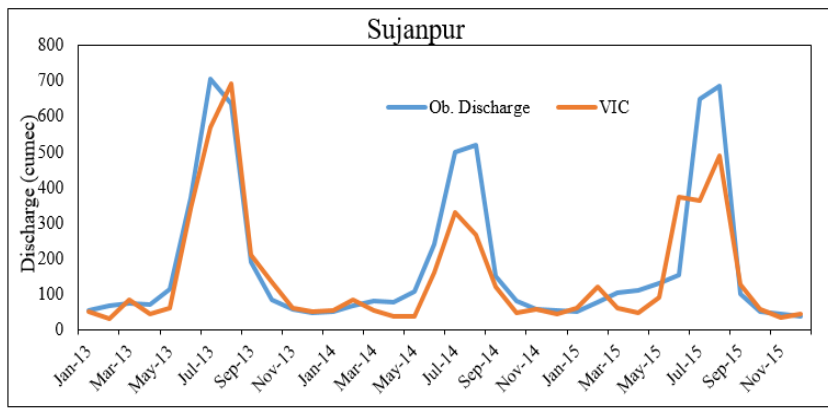

Figure 12 Validation plot of Simulated and observed Discharge at Sujanpur

The above plot shows that the simulated discharge follows the same pattern of the observed discharge. Mathematically, the validation is supported by finding the Nash-Sutcliffe efficiency 
between the discharges at both the outlets. It is 0.73 and 0.74 at Nadaun and Sujanpur outlets respectively. The validation is also supported by the scatter plots between the simulated and the observed values of discharges.

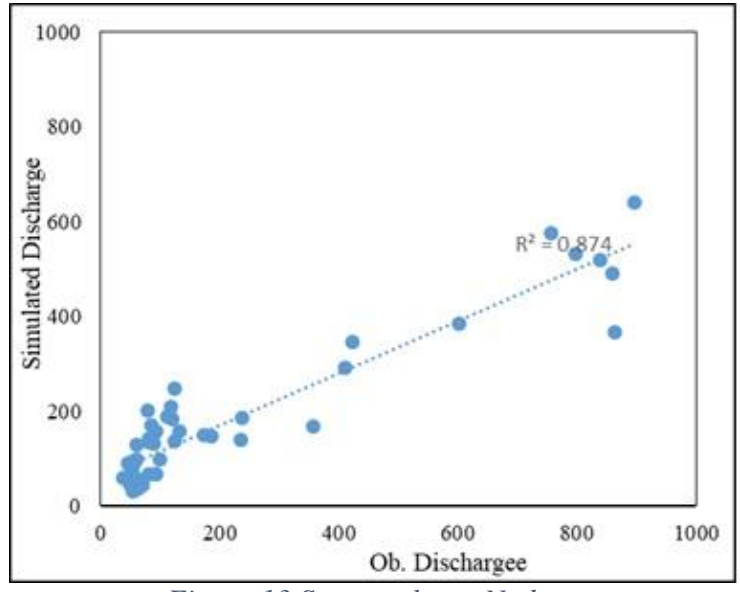

Figure 13 Scatter plot at Nadaun

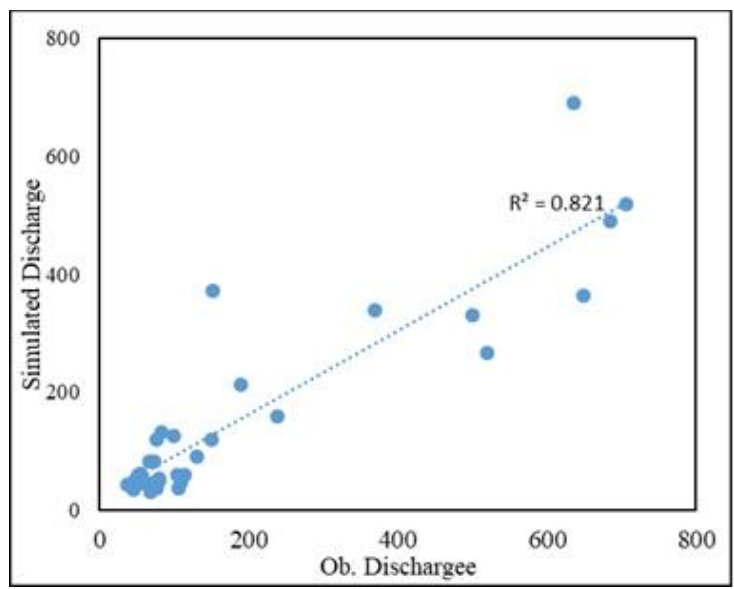

Figure 14 Scatter Plot at Sujanpur

The scatter plots in Figure 13 and Figure 14 show that the simulated values are highly correlated with the observed values and supports the validation of the model at Beas Basin. The coefficient of determination $\left(\mathrm{R}^{2}\right)$ is 0.87 at Nadaun outlet and 0.82 at Sujanpur outlet. It also supports the validation of the model. All the statistical parameters support the validation of the model at Baes basin.

\subsection{Historic Period (1979 - 2000)}

As Era - Interim dataset are available from 1979 onwards, the historic period is chosen from the year 1979 to 2000. The calibrated VIC model is employed for simulation of hydrological response of Beas Basin for historical time period (1979-2000). Using the simulation results of this model the discharge plots are generated, the flash flood threshold is identified (using historic reports and literature) and above which all the events are considered as flash flood events. Those flood events are matched with the events from the flood reports and news articles.

The historic flash flood reports are very less on records but still the listings are managed from 1990 onwards searched from various literature and published reports. The VIC simulated discharge at Nadaun and Sujanpur basin are shown in the Figure 15 and Figure 16.
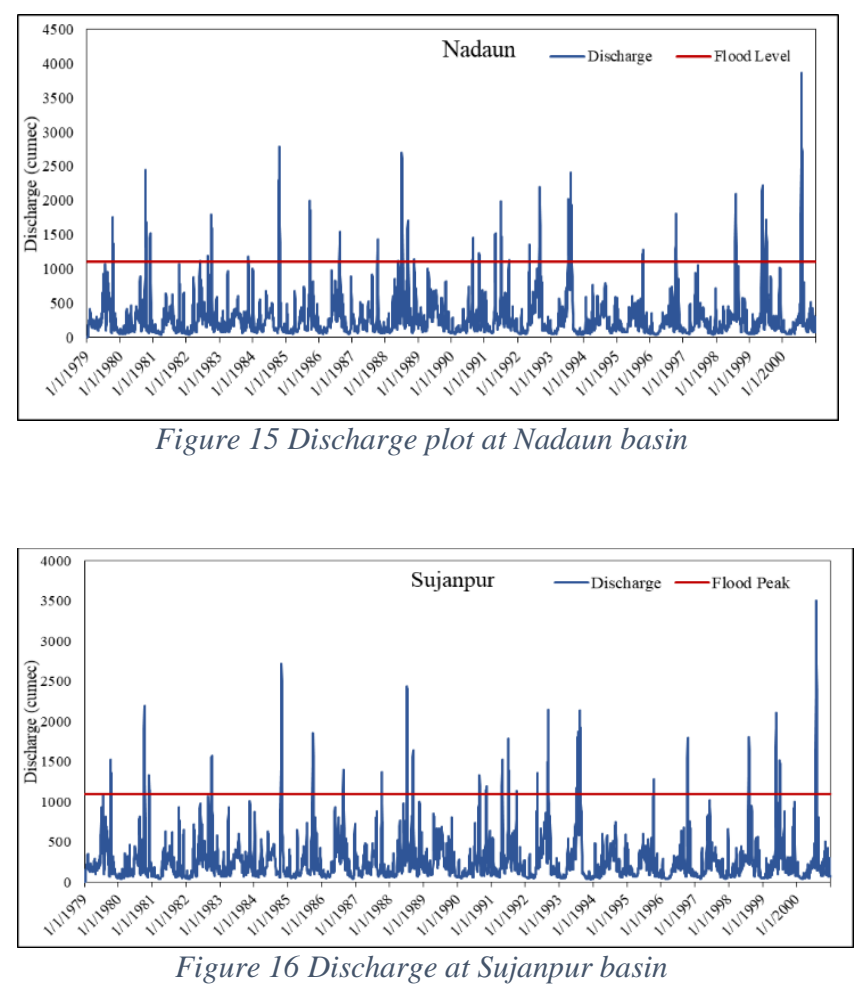

The flash flood events that have occurred due to heavy rain or cloud burst are reflected in the outlets at Nadaun and Sujanpur with frequent peaks. The numerous peaks are observed in this period. These are 1979, 1980, 1982, 1984, 1985, 1986, 1987 , 1988, 1990, 1991, 1992, 1993, 1996, 1998, 1999 and 2000. The Beas Basin receives the maximum annual rainfall out of all the basins of the North Western Himalaya (NWH). The flash floods that reflects in the reports matches with most of the events after 1990 as reports and literatures contains events after 1990 onwards. This suggest that the simulations have very well captured the extreme events occurred in the historic period.

\subsection{Present Period (2001 - 2017)}

The present period of study ranges from 2001 to 2017. This period is very crucial regarding the catastrophic extreme events in NWH. The extreme events have shown a increase in this period, though the mean annual rainfall has shown a decrease in trend. The 2010 Leh cloudburst, 2013 Kedarnath flash flood, 2014 Kashmir flood, 2017 cloudburst in Kullu and Manali, etc. are some major events that has cause serious destruction to the lives of the people. The model behavior in this period becomes very important as it covers the serious and recent water disasters.

The present period is considered from 2001 to 2017 . There is large number of flash flood events that have occurred in this period. The most serious and hazardous ones are 2001 (Kullu, Mandi, Kangra, Mandi), 2003 (Kullu), 2005, 2007, 2009, 2011, 2012, 2013, 2014, 2014, 2018 (Thakur et al. 2019). The plot for the simulated discharge data at both the outlets of the Beas Basin are shown in the Figure 17 and Figure 18. 


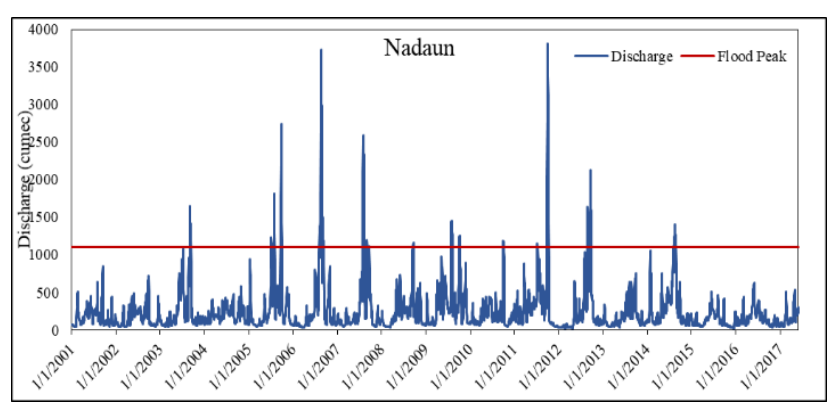

Figure 17 Discharge at Nadaun basin

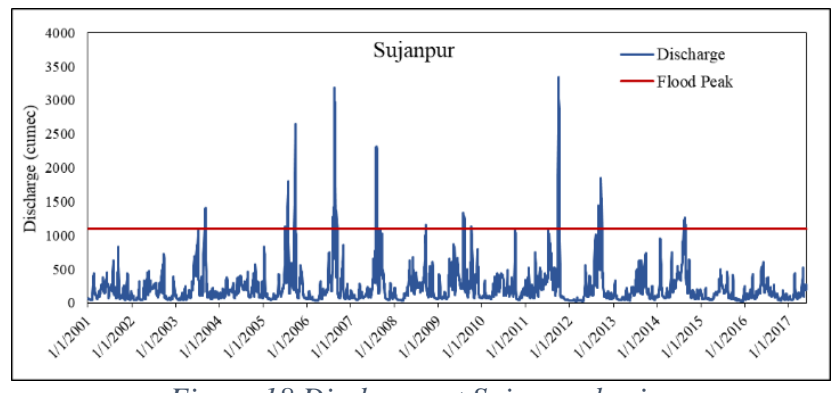

Figure 18 Discharge at Sujanpur basin

From the above simulated discharge for the present period, the flash flood events that are captured and reflected at the Nadaun and Sujanpur outlets by the hydrological model are 2003, 2005, 2006, 2007, 2009, 2010, 2011, 2012 and 2014. Among these the most of the flash floods records are matched with the literature and are supported by various reports.

\subsection{Future Period (2018 - 2099)}

The future period is also simulated to observe the behaviour of hydrological model. As the time period of the future simulation is very large hence, we have subdivided the future simulations into two parts- Near Future $(2018$ - 2050) and Far Future (2051 - 2099). The hydro-meteorological dataset used for the future simulations are bias corrected CORDEX data (Sharma et al. 2018, 2019).

The CORDEX data is available from the 2006 and we have also the observed data of Beas Basin for this time period. Hence, we simulate the model from year 2006 onwards. The starting 4 years of this period are taken as the warm up period for the model and we have plotted the discharge data obtained from the CORDEX (bias corrected) data with the observed data. The Figure 19 and Figure 20 show the plot of simulated discharge and observed discharge at Nadaun and Sujanpur outlet.

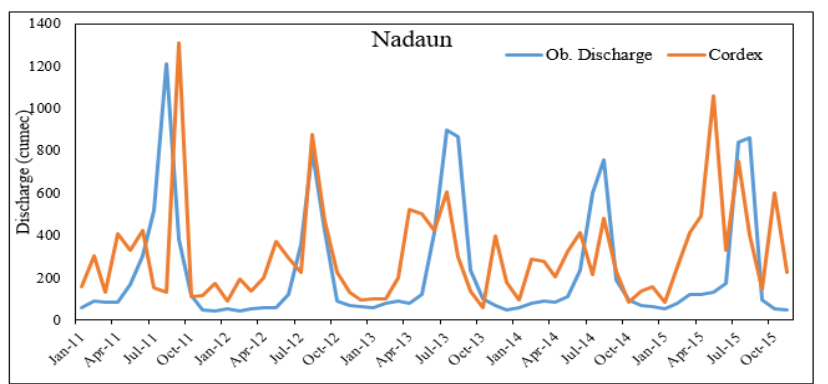

Figure 19 Simulated and observed discharge at Nadaun

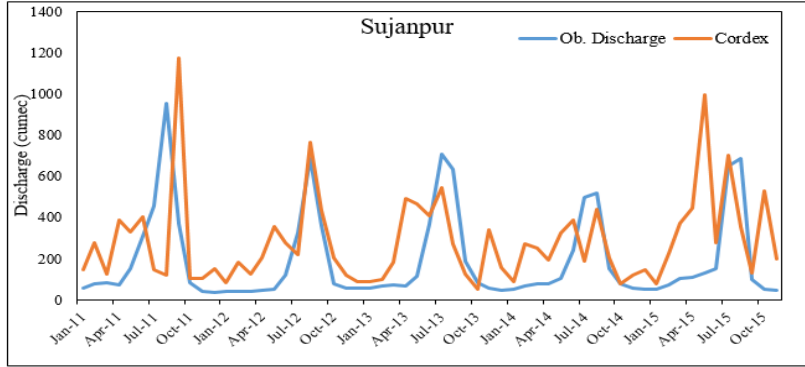

Figure 20 Simulated and observed discharge at Sujanpur

It is observed that simulated discharge is in good agreement with the observed discharge data. The occurrence of peak discharge is observed as shifted from the actual peak. It lets us to conclude that if any extreme event is captured by the future simulation (using CORDEX) then there is very high probability of occurring such extreme event in the close vicinity i.e. range around the actual observed date. It actually strengthen the probable occurrence of the extreme event in the area.

\section{Flood Peak Value Estimation for Future Period}

As the calibration and validation of the model is done with the ERA-Interim dataset hence, there is some bias in the peaks observed with other datasets due to bias in the input meteorological parameters. Hence, the flood peak value observed in the CODEX will also have some bias. For calculating the number of flood-extremes the flood peak value threshold needs to be identified for the hydrological output generated using CORDEX dataset. The exceedance curve methodology (Fatemi and Vafaie 2015; Goda, Wenzel, and Daniell 2015; Tian and Resconi 2018)is utilized in calculating the new flood peak threshold value for the basin. The percent exceedance curve is plotted for the common time period of both the datasets. The Figure 11 shows the exceedance curve of ERA-Interim dataset for the time period 2006 to 2017 at the Nadaun outlet of Beas Basin.

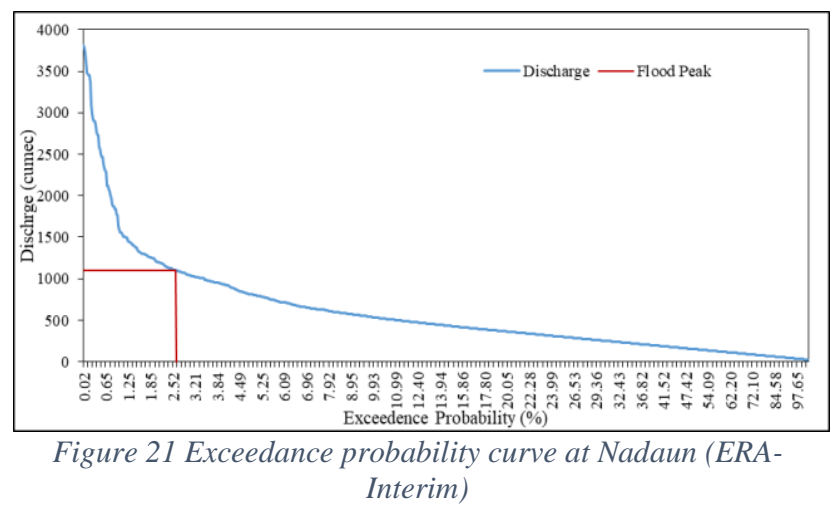

The flood peak value observed from the historic period is around $1100 \mathrm{~m}^{3} / \mathrm{sec}$. The percent exceedance found at this particular discharge is 2.6 and now at this exceedance value the new flood peak threshold value is obtained from the exceedance curve of the hydrological output derived using CORDEX data for the same time period (2006-2017). The percent exceedance curve for CORDEX dataset is shown in the Figure 22 at the same outlet i.e. Nadaun and for the same time period. 


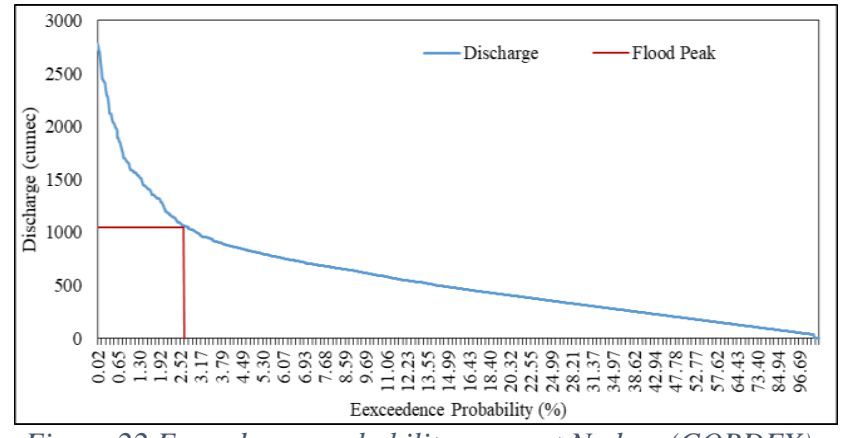

Figure 22 Exceedance probability curve at Nadaun(CORDEX)

The flood peak for the CORDEX data at $2.6 \%$ exceedance comes around $1050 \mathrm{~m}^{3} / \mathrm{sec}$. This value is considered as threshold for estimating the total number of flood extremes captured in the future period.

\subsection{Future Simulations}

The simulations of CORDEX (bias corrected) data is done in two periods - Near future and Far future.

4.5.1 Near Future Period (2018 - 2050)

The near future time period is taken from 2018 to 2050. The Beas Basin is simulated and discharge data is routed at two stations. One of them is Nadaun and the other station is Sujanpur. The hydrograph showing discharge in near future at the two outlets are shown in the Figure 23 and Figure 24.

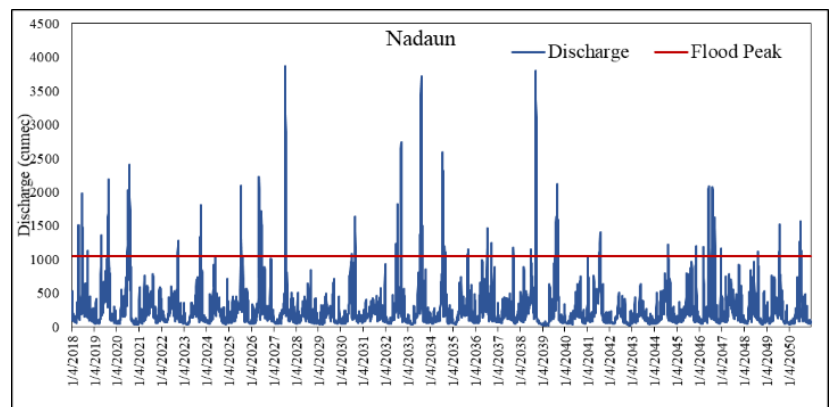

Figure 23 Simulated discharge at Nadaun outlet for near future period

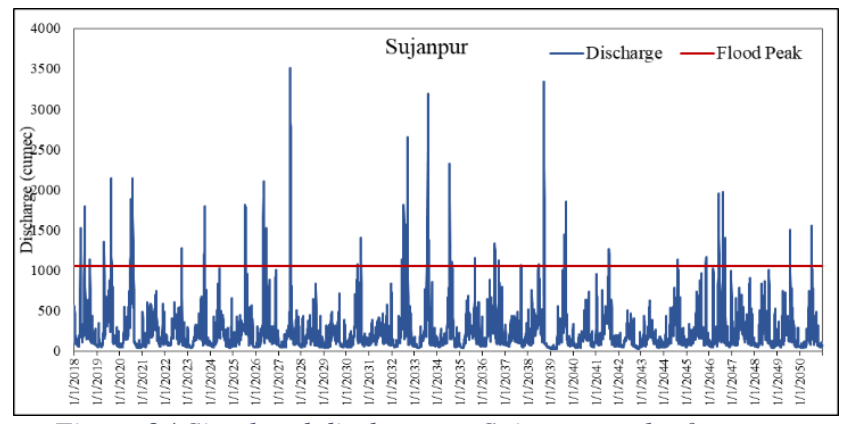

Figure 24 Simulated discharge at Sujanpur outlet for near future period

The above figures for the near future period also shows probable occurrence of the extreme events in the near future. It shows the probability of flash flood occurrence in year 2019, 2020, 2023, 2025, 2026, 2027 2032, 2033, 2034, 2038, 2039, 2046, 2049 and 2050. Among these the 2027, 2032, 2033, 2034 and 2038 are the most extreme among all. Year 2046 appears to be more prone to large number of flash flood extremes due to large number of 1day or 2-day extreme rainfall events.
4.5.2 Far Future Period (2051 - 2099)

The far future ranges from year 2051 to 2099. The hydrological simulations are generated using the CORDEX (bias corrected) data. The hydrological simulations at Nadaun and Sujanpur outlets are shown in Figure 25 and Figure 26.

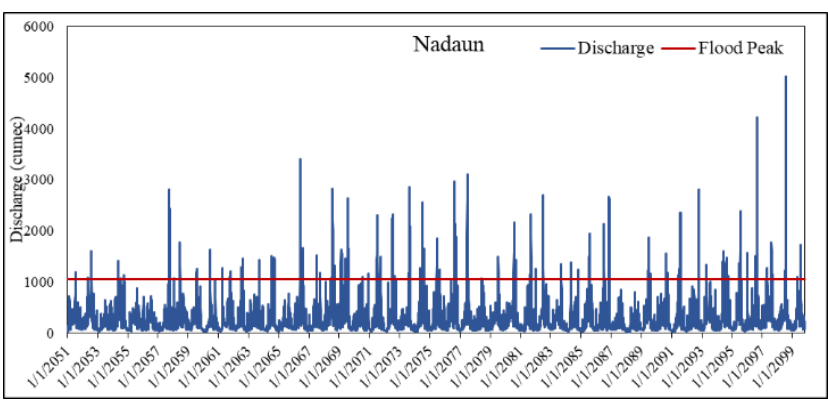

Figure 25 Simulated discharge at Nadaun outlet for far future time period

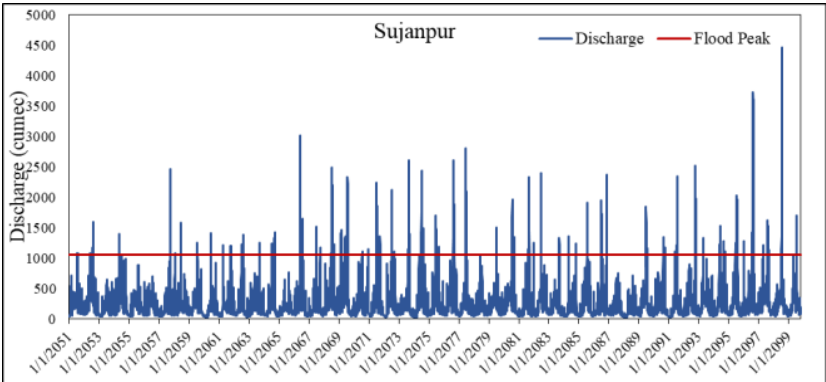

Figure 26 Simulated discharge at Sujanpur outlet for far future time period

The hydrographs above had indicated a large number of flood events in this period. The total number of hydrologic extremes indicated by the above hydrograph are close to 708 . Out of this more than half of the events will occur between 2065 and 2080. The CORDEX data has indicated a tremendous increase in the hydro-meteorological extremes in the far future period. The planning of the area lying in the Beas Basin should be more focused on preventing damage to lives and property of the dwellers of this basin.

4.6 Inter- Comparison of flood peak events in Historic, Present and Future Scenarios

The total occurrence of flood peaks over the three time spans is estimated and converted in occurrence of event per year scale to get the clear view of the temporally changing scenario over the Beas Basin. Table 2 shows the occurrence and rate of events occurred in the four time periods of study.

Table 2 Extremes Flood Events

\begin{tabular}{|l|r|r|r|}
\hline \multicolumn{1}{|c|}{$\begin{array}{c}\text { Time } \\
\text { Period }\end{array}$} & \multicolumn{1}{c|}{$\begin{array}{c}\text { Number } \\
\text { of Events }\end{array}$} & \multicolumn{1}{c|}{$\begin{array}{c}\text { Total number } \\
\text { of Years }\end{array}$} & Rate/year \\
\hline Historic & 201 & 22 & 9.14 \\
\hline Present & 153 & 17 & 9.00 \\
\hline $\begin{array}{l}\text { Near } \\
\text { Future }\end{array}$ & 388 & 33 & 11.76 \\
\hline Far Future & 708 & 49 & 14.45 \\
\hline
\end{tabular}

The plot is also generated showing the occurrence of flood extremes per year in different time periods and is shown in Figure 27. 


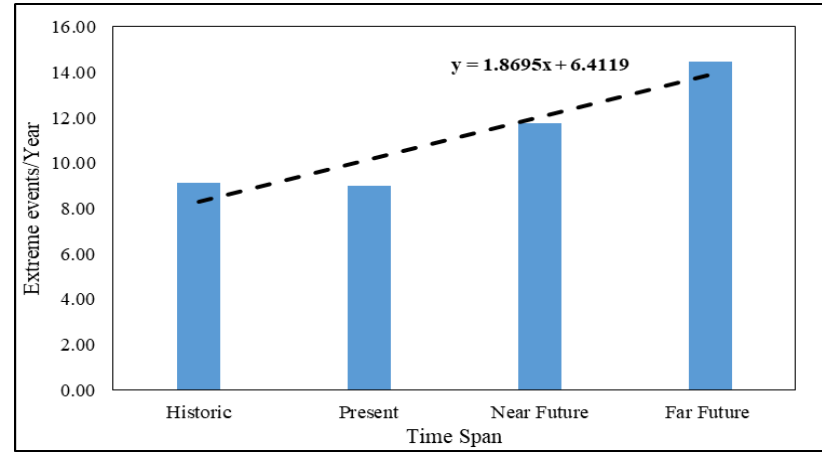

Figure 27 Extreme Flood Peaks Trend over time period

The Figure 27 and Table 2 shows that the due to changing climate the number of extreme events are showing increasing trend and in the far future period the increase in the extreme events per year is very high.

\section{CONCLUSION}

The above study has strengthened the fact that the climate change has leads to the increase in the number of hydro-meteorological extremes. It has been observed that the Beas Basin is highly affected with the cloudburst causing series of flash flood in the region. The hydrological simulations performed for the three time periods has shown that the hydrologic extremes are on increases from past to present period and will increase with higher rate in the future period. The historic simulations have shown that the ERA - Interim datasets have captured most of the hydrologic extremes when compared with the historical reports. The severe cloudburst in year1997 near Kullu and Manali have also been captured by the hydrological simulations. The present period had shown high frequency in the occurrence of extreme events and has resulted a huge loss to life and property in the region. This increase in the rainfall extremes and is supported by the hydrological results of the Beas Basin which shows increase in the hydrologic extremes during this time period.

The future simulations for the period of 2018- 2099 has also shown increase in hydro-meteorological extreme events in the coming years. The CORDEX data utilised is available from 2006 onwards and hence the model is simulated from the 2006 and considering model warm up period to be five years, the hydrological simulations from 2011 to 2017 when compared with the observed data available shows that it had also captured various hydrological extremes during the 2011 and 2017. Hence this finding helps us to conclude that there is fair probability of the occurrence of hydrological extremes in the near future as captured by the CORDEX simulations. The future period has shown that there is increase in the hydrological extremes in the future with tremendous increase in the far future period (20512099). The study has strengthened the fact that modelling approach has shown its worth in the estimation of the hydrometeorological extreme over the long time period. As the observed data is not available for such a long period, modelling approach acts as an helping hand in understanding the changing trend from past to present and also it can predict its occurrence in future. The prediction of trend in future can be considered very beneficial for the development and planning of the region.

\section{REFERENCES}

Aggarwal, S. P., Thakur, P. K., Garg, V., Nikam, B. R., Chouksey, A., Dhote, P., \& Bhattacharya, T. (2016). Water Resources Status and Availability Assessment in Current and Future Climate Change Scenarios for Beas River Basin of North Western Himalaya. ISPRS - International Archives of the
Photogrammetry, Remote Sensing and Spatial Information Sciences, XLI-B8(July), 1389-1396. https://doi.org/10.5194/isprs-archives-xli-b8-1389-2016

Behera S. S., Nikam B. R., Babel M. S., Garg V. and Aggarwal S. P., 2019. The Assimilation of remote sensing derived soil moisture data into a hydrological model for the Mahanadi baisn, India. Journal of Indian Society of Remote Sensing, 10.1007/s12524-019-00954-2.

Cell, Disaster Management. 2012. 'State Disaster Management Plan, 2012 Himachal Pradesh'.

D. LOHMANN, E. RASCHKE, B. NIJSSEN \& D. P. LETTENMAIER. 2003. 'Regional Scale Hydrology: I. Formulation of the VIC-2L Model Coupled to a Routing Model'. Eastern Mediterranean Health Journal 9(4): 509-17.

Dhote, Pankaj R. ,Thakur, Praveen K., Aggarwal, S. P.,Sharma, Vimal C.,Garg, Vaibhav,Nikam, Bhaskar R., Chouksey, Arpit. 2018. 'Experimental Flood Early Warning System in Parts of Beas Basin Using Integration of Weather Forecasting, Hydrological and Hydrodynamic Models'. International Archives of the Photogrammetry, Remote Sensing and Spatial Information Sciences - ISPRS Archives 42(5): 221-25.

Dimri, A. P., Chevuturi, A., Niyogi, D., Thayyen, R. J., Ray, K., Tripathi, S. N., Pandey, A. K., Mohanty, U. C. 2017. 'Cloudbursts in Indian Himalayas: A Review'. Earth-Science Reviews 168: 1-23.

Donnelly, Chantal, Wei Yang, and Joel Dahné. 2014. 'River Discharge to the Baltic Sea in a Future Climate'. Climatic Change 122(1): 157-70. https://doi.org/10.1007/s10584-0130941-y.

Fatemi, Seyed Ehsan, and Freydon Vafaie. 2015. 'A New Habitat Methodology for River Environmental Flow Requirements'. Proceedings of the Institution of Civil Engineers - Water Management 168(3): 105-15. https://doi.org/10.1680/wama.13.00057.

Garg V., Aggarwal S.P., Gupta P. K., Nikam B. R. and Thakur P. K., 2017. Assessment of land use land cover change impact on hydrological regime of a basin. Environmental Earth Sciences, 76, 635. doi: 10.1007/s12665-017-6976-z.

Garg V., Nikam B.R., Thakur P.K., Gupta P.K., Aggarwal S.P. and Srivastav S.K., 2019. Human-Induced Land Use Land Cover Change and its Impact on Hydrology. HydroResearch, 1, 48-56, doi.org/10.1016/j.hydres.2019.06.001.

Goda, Katsuichiro, Friedemann Wenzel, and James Edward Daniell. 2015. 'Insurance and Reinsurance Models for Earthquake BT - Encyclopedia of Earthquake Engineering'. In eds. Michael Beer, Ioannis A Kougioumtzoglou, Edoardo Patelli, and Siu-Kui Au. Berlin, Heidelberg: Springer Berlin Heidelberg, 1184-1206. https://doi.org/10.1007/978-3-642-35344-4_261.

Gupta, R. P., Duggal, A. J., Rao, S. N., Sankar, G., \& Singhal, B. B. S. (1982). Snow-cover area vs. snowmelt runoff relation and its dependence on geomorphology - A study from the Beas catchment (Himalayas, India). Journal of Hydrology, 58(3), 325339. 1694(82)90042-7

Gunderson, Jake A, Eric Heatwole, Peter Dickson, and Gary R 
Parker. 1996. 'A Grit-Surface Interaction Model for Frictional Ignition of PBX 9501'. 101(1): 603-10.

Hattermann, Fred F. 2019. 'Climate Change Impacts on HydroMeteorological Extremes - Are There Robust Signals?' 21: 16228.

Jaume Terradas, and Josep Peñuelas. 2008. 'Climate Change Policy: IPCC Consensus Is Not Enough'. Ambio 37(4): 32122.http://www.jstor.org/stable/25547904\%5Cnhttp://www.jstor. org/stable/25547904.

Liang, X., D. P. Lettenmaier, E. F. Wood, and S. J. Burges. 1994. 'A Simple Hydrologically Based Model of Land Surface Water and Energy Fluxes for GSMs'. J. Geophys. Res. 99(D7): 1441528.

Liang, $\mathrm{Xu}$, Dennis P Lettenmaier, and Eric F Wood. 1996. 'OneDimensional Statistical Dynamic Representation of Subgrid Spatial Variability of Precipitation in the Two-Layer Variable Infiltration Capacity Model'. Journal of Geophysical Research: Atmospheres 101(D16): 21403-22. https://agupubs.onlinelibrary.wiley.com/doi/abs/10.1029/96JD0 1448 .

Liang, Xu, Eric F. Wood, and Dennis P. Lettenmaier. 1996. 'Surface Soil Moisture Parameterization of the VIC-2L Model: Evaluation and Modification'. Global and Planetary Change 13(1-4): 195-206.

Lohmann, D., Nolte-Holube, R. and Raschke, E. 1996. 'A Large Scale Horizontal Routing Model to Be Coupled to Land Surface Parameterization Schemes.' Tellus 48A: 708-21.

Lohmann, D, E Raschke, B Nijssen, and D P Lettenmaier. 1998. 'Regional Scale Hydrology: I. Formulation of the VIC-2L Model Coupled to a Routing Model'. Hydrological Sciences Journal 43(1): 131-41. https://doi.org/10.1080/02626669809492107.

LOHMANN, D, E RASCHKE, B NIJSSEN, and D $P$ LETTENMAIER. 1998. 'Regional Scale Hydrology: II. Application of the VIC-2L Model to the Weser River, Germany'. Hydrological Sciences Journal 43(1): 143-58. https://doi.org/10.1080/02626669809492108.

McMahan, Andrew C, Catherine N Grover, and Frank E Vignola. 2013. 'Chapter 4 - Evaluation of Resource Risk in Solar-Project Financing'. In ed. Jan B T - Solar Energy Forecasting and Resource Assessment Kleissl. Boston: Academic Press, 81-95. http://www.sciencedirect.com/science/article/pii/B97801239717 77000048 .

Naha, S., Thakur, P. K., \& Aggarwal, S. P. (2016). Hydrological modelling and Data Assimilation of satellite snow cover area using a Land Surface Model, VIC. International Archives of the Photogrammetry, Remote Sensing and Spatial Information Sciences - ISPRS Archives, 41(July), 353-360. https://doi.org/10.5194/isprsarchives-XLI-B8-353-2016

Nijssen, Bart., Lettenmaier, Dennis P., Liang, Xu., Wetzel, Suzanne W., Wood, Eric F 1997. 'Streamflow Simulation for Continental-Scale River Basins and Radiative Forcings ) Applications of the Model to the Columbia and Annual Flow Volumes to within a Few Percent . Difficulties in Reproducing the Sa6ramento Model [ Burnash Is Dominated Using An'. Water Resource Research 33(4): 711-24.
Nikam B. R., Garg V., Jaya K., Gupta P. K., Srivastav S. K., Thakur P. K. and Aggarwal S. P., 2018. Analyzing Future Water Availability and Hydrological Extremes in Krishna Basin under Changing Climatic Conditions. Arabian Journal of Geosciences, 11(19), 581. 10.1007/s12517-018-3936-1.

Pechlivanidis, I G.,Arheimer, B., Donnelly, C/. Hundecha, Y., Huang, S., Aich, V., Samaniego, L., Eisner, S., Shi, P 2017. 'Analysis of Hydrological Extremes at Different Hydro-Climatic Regimes under Present and Future Conditions'. Climatic Change 141(3): 467-81. https://doi.org/10.1007/s10584-016-1723-0.

Prasad, V. H., \& Roy, P. S. (2005). Estimation of Snowmelt Runoff in Beas Basin, India. Geocarto International, 20(2), 4147. https://doi.org/10.1080/10106040508542344

Sati, S. P., and V. K. Gahalaut. 2013. 'The Fury of the Floods in the North-West Himalayan Region: The Kedarnath Tragedy'. Geomatics, Natural Hazards and Risk 4(3): 193-201.

Sharma, V., Pandey, K., Thakur, P. K., Aggarwal, S. P., Nikam, B. R., Dhasmana, M. K., ... Singh, S. (2018). Seasonal Comparison of Era-Interim Precipitation Dataset for Entire Indian Region. ISPRS - International Archives of the Photogrammetry, Remote Sensing and Spatial Information Sciences, XLII(November), 20-23. https://doi.org/10.5194/isprsarchives-XLII-5-567-2018

Sharma, V., Nikam, B. R., Thakur, P. K., Garg, V., and Aggarwal, S. P. (2019). Effect of Bias Correction in Era-Interim Precipitation Dataset on the Behaviour of Hydrological Model. In Proceedings of 'HYDRO 2019 INTERNATIONAL', 24 ${ }^{\text {th }}$ International Conference on Hydraulics, Water Resources, Coastal \& Environmental Engineering, December 18-20, 2019, At Osmania University, Hyderabad, India.

Thakur, Praveen K., Aggarwal, S P., Dhote, Pankaj., Nikam, Bhaskar R., Garg, Vaibhav., Bhatt, C M., Chouksey, Arpit., Jha, Ashutosh. 2019. 'Hydrometeorological Hazards Mapping, Monitoring and Modelling BT - Remote Sensing of Northwest Himalayan Ecosystems'. In eds. R R Navalgund, A Senthil Kumar, and Subrata Nandy. Singapore: Springer Singapore, 139-69. https://doi.org/10.1007/978-981-13-2128-3_7. 2019b. Hydrometeorological Hazards Mapping , Monitoring and Modelling.

Thayyen, Renoj, A P Dimri, Pradeep Kumar, and P Agnihotri. 2013. 'Study of Cloudburst and Flash Floods around Leh, India during August 4-6, 2010'. Natural Hazards 65: 2175-2204.

Tian, Jing, and Germano Resconi. 2018. 'Morphogenetic Updating Algorithm and Its Application in Updating Probabilistic Risk'. International Journal of Pattern Recognition and Artificial Intelligence 33(07): 1950008 https://doi.org/10.1142/S0218001419500083.

Towler, Erin., Rajagopalan, Balaji., Gilleland, Eric., Summers, R., Yates, David., Katz, Richard 2010. 'Modeling Hydrologic and Water Quality Extremes in a Changing Climate: A Statistical Approach Based on Extreme Value Theory'. Water Resources Research - WATER RESOUR RES 46. 